\title{
PENGARUH PARTISIPASI SISWA DALAM ORGANISASI KESISWAAN DAN PERILAKU BELAJAR TERHADAP PRESTASI BELAJAR MATEMATIKA
}

\author{
KURNIAWAN \\ SMK Negeri 13 Kota Bekasi \\ e-mail : e1_nstein@ymail.com
}

\begin{abstract}
ABSTRAK
Penelitian ini bertujuan untuk mengetahui sejauh mana partisipasi siswa dalam organisasi kesiswaan dan perilaku belajar terhadap prestasi belajar matematika. Metode penelitian yang digunakan dalam penelitian ini adalah metode survei. Teknik analisis data dengan menggunakan regresi ganda. Besar sampel sebanyak 95 siswa yang diambil secara simple random sampling. Instrumen yang digunakan adalah angket/kuesioner untuk mengukur partisipasi siswa dalam organisasi kesiswaan dan perilaku belajar, serta dokumentasi nilai raport untuk melihat prestasi belajar matematika. Hasil uji hipotesisnya yaitu : (1) Terdapat pengaruh yang signifikan partisipasi siswa dalam organisasi kesiswaan dan perilaku belajar secara bersama-sama terhadap prestasi belajar matematika (2) Terdapat pengaruh yang signifikan partisipasi siswa dalam organisasi kesiswaan terhadap prestasi belajar matematika (3) Terdapat pengaruh yang signifikan perilaku belajar terhadap prestasi belajar matematika.
\end{abstract}

Kata kunci : Partisipasi siswa, organisasi kesiswaan, perilaku belajar, prestasi belajar matematika

\section{ABSTRACT}

This study aims to determine the extent of student participation in student organizations and learning behavior on mathematics learning achievement. The research method used in this study is a survey method. Data analysis technique using multiple regression. The sample size is 95 students taken by simple random sampling. The instrument used is a questionnaire/questionnaire to measure student participation in student organizations and learning behavior, as well as documentation of report cards to see mathematics learning achievement. The results of the hypothesis test are: (1) There is a significant effect of student participation in student organizations and learning behavior together on mathematics learning achievement (2) There is a significant effect of student participation in student organizations on mathematics learning achievement (3) There is a significant effect significant learning behavior on learning achievement in mathematics.

Keywords: Student participation, student organization, learning behavior, mathematics learning achievement

\section{PENDAHULUAN}

Prestasi belajar merupakan suatu bentuk pencapaian atas usaha seseorang setelah melalui kegiatan belajar yang berupa penguasaan materi, keterampilan, maupun pengetahuan yang ditunjukkan ataupun diwakilkan dalam bentuk nilai. Jika dikaitkan dengan pelajaran matematika, maka prestasi belajar matematika dapat diartikan sebagai hasil yang didapat siswa setelah melalui proses pembelajaran yang menggambarkan kemampuan siswa terhadap materi pelajaran matematika yang dilihat dari nilai matematika yang diperoleh siswa, baik dalam bentuk raport, indeks prestasi, angka atau predikat keberhasilan.

Di Indonesia, matematika menjadi salah satu mata pelajaran yang dianggap sangat sulit, Berdasarkan data Kemendikbud (2018) laporan survei yang dilakukan oleh Programme for International Student Assessment (PISA) di bawah Organization Economic Cooperation and Development (OECD) yang dilakukan pada 78 negara di dunia tahun 2018 lalu, mengatakan bahwa kemampuan matematika siswa-siswi di Indonesia menduduki peringkat bawah (rangking ke-72) dengan skor 379 (rata-rata OECD 489). Sementara studi yang dilakukan oleh TIMSS (Trend in International Mathematics and Science Study Trend in International 


\section{SCIENCE : Jurnal Inovasi Pendidikan Matematika dan IPA Vol. 1 No. 3 November 2021 e-ISSN : 2797-1031 | p-ISSN : 2797-0744}

Mathematics and Science Study) tahun 2015 di bawah naungan The International Association for the Evaluation of Educational Achievement (IEA) menyatakan bahwa kemampuan siswasiswi di Indonesia menduduki peringkat ke-45 dari 50 negara dengan skor 397. Kurang dari 1 persen siswa Indonesia yang memiliki kemampuan bagus di bidang matematika. Hal ini sangat memprihatinkan bagi dunia pendidikan Indonesia.

Matematika memiliki peranan yang sangat penting dalam kehidupan sehari-hari, contohnya adalah dalam transaksi jual-beli yang sering dilakukan oleh setiap orang, pasti menggunakan operasi berhitung yang ada di dalam matematika. Dengan belajar matematika, secara tidak langsung melatih siswa untuk berfikir rasional dan lebih menggunakan logika. Tidak hanya itu, matematika juga sangat berperan penting dalam bidang teknologi dan ilmu sains. Kita mungkin sudah tahu, bagaimana sebuah teknologi yang canggih hanya digerakkan oleh kombinasi angka 0 dan 1 (biner) yang di dalamnya memuat logika matematika yang dirangkai dalam suatu program komputer.

Peranan yang penting dari matematika ternyata tidak diimbangi dengan prestasi belajar yang diperoleh oleh siswa-siswi di sekolah. Hal ini dapat dilihat dari data Kemendikbud (2018) tentang hasil UN SMK pada mata pelajaran matematika tahun 2017 dan 2018, dimana matematika menjadi mata pelajaran dengan nilai terkecil dari 4 mata pelajaran yang diujikan. Rata-rata nilai UN matematika tahun 2017 untuk tingkat nasional 36,81, tingkat provinsi Jawa Barat 33,78 dan tingkat Kabupaten Bogor 30,67. Sedangkan rata-rata nilai UN matematika tahun 2018 untuk tingkat nasional adalah 33,73, tingkat provinsi Jawa Barat 31,41, dan tingkat Kabupaten Bogor 29,91. Permasalahan nilai UN matematika tingkat Kabupaten Bogor menjadi hal yang harus diperhatikan karena posisinya berada pada 3 terbawah di tingkat provinsi (dari 27 kabupaten/kota) pada tahun 2017, dan posisi 7 terbawah pada tahun 2018.

Berdasarkan data nilai UN SMK 2 tahun terakhir di atas, terlihat jelas bahwa terjadi trend penurunan nilai UN matematika untuk tingkat nasional sebesar 3,08. Tingkat provinsi Jawa Barat 2,37, dan tingkat Kabupaten Bogor 0,76.

Masih banyak siswa yang memandang bahwa matematika sebagai mata pelajaran yang paling sulit. Menurut Masykur dan Fathani (2007), berdasarkan hasil penelitian di Indonesia, disebutkan bahwa tingkat penguasaan siswa dalam matematika pada semua jenjang pendidikan masih sekitar 34\%. Banyak siswa yang mengalami masalah dalam belajar akibatnya prestasi belajar yang dicapai rendah. Untuk mengatasi hal tersebut perlu ditelusuri faktor yang mempengaruhi rendahnya prestasi belajar matematika.

Meningkatkan prestasi belajar matematika sangatlah penting, karena matematika membekali siswa dengan kemampuan berpikir logis, analitis, sistematis, kritis dan kreatif serta kemampuan bekerja sama (Depdiknas, 2007). Belajar matematika membuat siswa dapat bernalar secara kritis, menambah kreatifitas, dan aktif dalam menyelesaikan segala macam persoalan, karena matematika dapat menumbuhkembangkan kemampuan belajar untuk belajar, sehingga akan meningkatkan dalam mempersiapkan diri menjadi pembelajar sepanjang hayat.

Dengan matematika ilmu mengalami perkembangan dari kualitatif ke kuantitatif, sehingga peran matematika sangat penting dalam perkembangan berbagai ilmu pengetahuan, karena matematika merupakan ilmu deduktif. Matematika memprediksi keberhasilan seseorang, jika seorang siswa berhasil mempelajari matematika dengan baik maka ia di prediksikan berhasil juga mempelajari mata pelajaran lain. Begitu juga sebaliknya, seorang anak yang kesulitan mempelajari matematika akan kesulitan juga mempelajari mata pelajaran lain.

Menurut Ahmadi dan Supriyono (2004), prestasi belajar yang dicapai seseorang merupakan hasil interaksi berbagai faktor yang mempengaruhinya baik dalam diri (faktor internal) dan dari luar (faktor eksternal).

Faktor internal meliputi faktor jasmaniah, psikologi, dan faktor kematangan fisik maupun psikis. Faktor jasmaniah antara lain panca indera yang tidak berfungsi sebagaimana mestinya, berfungsinya kelenjar tubuh yang membawa kelainan tingkah laku. Sedangkan faktor 


\section{SCIENCE : Jurnal Inovasi Pendidikan Matematika dan IPA Vol. 1 No. 3 November 2021 e-ISSN : 2797-1031 | p-ISSN : 2797-0744}

psikologi antara lain kecerdasan, bakat, sikap, kebiasaan, minat, kebutuhan, dan motivasi (Ahmadi \& Supriyono, 2004).

Faktor eksternal berupa faktor sosial, budaya, lingkungan fisik, dan lingkungan spiritual keagamaan. Faktor sosial meliputi lingkungan keluarga, sekolah, dan masyarakat. Faktor budaya meliputi adat istiadat, ilmu pengetahuan, teknologi, dan kesenian. Faktor lingkungan fisik seperti fasilitas rumah dan fasilitas belajar. Fasilitas belajar meliputi ruang belajar, meja, kursi penerangan, alat tulis, dan buku-buku pelajaran. Faktor tersebut saling berinteraksi baik secara langsung maupun tidak langsung dalam mempengaruhi prestasi belajar. (Ahmadi \& Supriyono, 2004).

Sebagaimana disebutkan di atas, bahwa salah satu faktor yang mempengaruhi prestasi belajar dari sisi faktor eksternal adalah lingkungan sekolah. Lingkungan sekolah yang dimaksud di sini adalah bagaimana siswa bergaul dengan siswa lain dalam sebuah lembaga/organisasi kesiswaan yang ada di sekolah, yang dalam hal ini dinaungi oleh Organisasi Siswa Intra Sekolah (OSIS), yang di dalamnya juga mengatur beberapa sub organisasi kecil pembantu dalam bentuk kegiatan-kegiatan ekstrakurikuler.

Hal ini sesuai dengan apa yang diamanatkan dalam Peraturan Menteri Pendidikan Nasional Republik Indonesia Nomor 39 Tahun 2008 tentang Pembinaan Kesiswaan, yang menyebutkan bahwa "pembinaan kesiswaan dilaksanakan melalui kegiatan ekstrakurikuler dan kokurikuler. Salah satu lembaga yang menaungi bentuk kegiatan tersebut di sekolah adalah Organisasi Siswa Intra Sekolah (OSIS)”.

Sebagai satu-satunya wadah kegiatan siswa di sekolah, OSIS memiliki peranan yang sangat penting dalam rangka mengembangkan potensi siswa, yaitu : (1) Sebagai fasilitator kegiatan sekolah, seperti dalam latihan dasar kepemimpinan, kegiatan ekstrakurikuler, dan aktivitas wiyata mandala. (2) Sebagai pendorong bagi anggotanya dan siswa lainnya dalam lingkup internal untuk memberikan motivasi dan inisiatif berbuat positif dan bergerak bersamasama untuk mencapai suatu tujuan. (3) Sebagai pencegah pengaruh negatif baik dari internal maupun eksternal.

Dengan siswa ikut berpartisipasi dalam organisasi kesiswaan, yaitu kegiatan OSIS dan ekstrakurikuler, secara tidak langsung akan meningkatkan prestasi belajar siswa. Dikarenakan banyak sekali manfaat yang didapat setelah siswa ikut berpartisipasi dalam organisasi OSIS dan ekstrakurikuler. Diantaranya siswa menjadi lebih disiplin, berani, bertanggung jawab, kreatif, percaya diri, dan lain-lain. Manfaat-manfaat yang didapat tersebut, akan sangat membantu siswa dalam proses kegiatan belajar mengajar di kelas. Yaitu siswa menjadi lebih aktif di kelas atau perilaku belajar siswa meningkat.

Sedangkan faktor berikutnya yang mempengaruhi prestasi belajar dari sisi faktor internal adalah kebiasaan. Kebiasaan yang dimaksud dalam hal ini adalah kebiasaan belajar, yang mana bisa ditafsirkan sebagai perilaku belajar, hal ini sesuai dengan apa y ang diungkapkan oleh Syah (2010), bahwa "manifestasi atau perwujudan perilaku belajar biasanya lebih sering tampak dalam perubahan-perubahan : kebiasaaan, keterampilan, pengamatan, berpikir asosisatif dan daya ingat, berpikir rasional, sikap, inhibisi, apresiasi, dan tingkah laku efektif."

Perilaku belajar dalam wujud kebiasaan maksudnya adalah bahwa setiap siswa yang telah mengalami proses belajar, kebiasaannya/perilakunya akan berubah. Kebiasaan itu timbul karena proses penyusutan respon menggunakan stimulus yang berulang, pembiasaan juga meliputi pengurangan perilaku yang tidak diperlukan karena proses penyusutan inilah yang baru dan menjadi kebiasaan baru. Perilaku belajar yang baik akan berpengaruh terhadap prestasi belajar yang baik, begitu pula sebaliknya.

Dalam konteks penulis selaku wakil kepala sekolah bidang kesiswaan yang juga merupakan guru di sekolah, maka penulis sangat tertarik mengambil keterkaitan prestasi belajar siswa dengan faktor-faktor yang mempengaruhinya, baik secara eksternal maupun internal, yaitu partisipasi siswa dalam kegiatan kesiswaan (OSIS dan ekstrakurikuler) dan perilaku belajar siswa. 
Berdasarkan hal yang sudah diuraikan di atas, maka penulis mengadakan penelitian dengan judul : Pengaruh Partisipasi Siswa Dalam Organisasi Kesiswaan dan Perilaku Belajar Terhadap Prestasi Belajar Matematika Siswa SMK Negeri di Kabupaten Bogor.

\section{METODE PENELITIAN}

Metode penelitian yang digunakan penulis adalah metode survei. Menurut Sugiyono (2013) pengertian metode survei adalah penelitian yang dilakukan dengan menggunakan angket sebagai alat penelitian yang dilakukan pada populasi besar maupun kecil, tetapi data yang dipelajari adalah data dari sampel yang diambil dari populasi tersebut, sehingga ditemukan kejadian relatif, distribusi, dan hubungan antar variabel, sosiologis maupun psikologis.

Penelitian dilaksanakan pada SMK Negeri di Kabupaten Bogor pada bulan Desember 2018 sampai dengan Januari 2019. Jumlah sampel dalam penelitian ini sebanyak 95 siswa yang diambil secara simple random sampling.

Adapun desain penelitian adalah sebagai berikut :

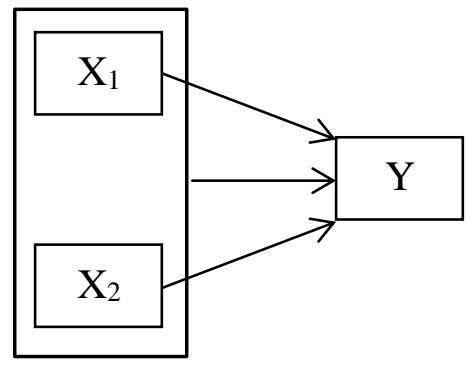

\section{Gambar 1. Desain Penelitian}

Keterangan :

$\mathrm{X}_{1}$ : Variabel bebas partisipasi siswa dalam organisasi kesiswaan

$\mathrm{X}_{2}$ : Variabel bebas perilaku belajar

Y : Variabel terikat Prestasi belajar siswa

$\rightarrow$ : garis korelasi

Analisis data menggunakan regresi linier berganda, adalah hubungan secara linier antara variabel bebas $\mathrm{X}_{1}$ dan $\mathrm{X}_{2}$ dengan variabel terikat $\mathrm{Y}$, digunakan untuk mengetahui arah hubungan antara variabel bebas dan variabel terikat, dan memprediksi nilai dari variabel terikat apabila nilai variabel bebas mengalami kenaikan atau penurunan.

Terdapat tiga jenis variabel penelitian, yaitu partisipasi siswa dalam organisasi kesiswaan dan perilaku belajar yang pengambilan datanya menggunakan angket/kuesioner, serta prestasi belajar matematika yang datanya diambil secara dokumentasi dengan melihat hasil buku raport. Untuk instrumen dalam bentuk angket/kuesioner, sebelumnya instrumen tersebut diujicoba untuk dilihat validitas dan reliabilitasnya, hal tersebut dimaksudkan untuk mengetahui kelayakan instrumen untuk dijadikan sebagai instrumen penelitian.

\section{HASIL DAN PEMBAHASAN}

\section{Hasil}

Uji linieritas dilakukan dengan melihat nilai $\mathrm{F}$ (Deviation from linearity). Berdasarkan hasil pengujian Linearitas Regresi Variabel $Y$ atas $X_{1}$ diperoleh nilai $F_{\text {hitung }}=1,337$ dan dan Sig. $=0,162>0,05$. Sementara hasil pengujian variabel $\mathrm{Y}$ atas $\mathrm{X}_{2}$ diperoleh nilai $\mathrm{F}_{\text {hitung }}=1,214$ dan Sig. $=0,277>0,05$. Karena nilai $F_{\text {hitung }}$ dan nilai Sig. $>0,05$, maka disimpulkan terdapat hubungan yang linier antara variabel $\mathrm{X}_{1}$ terhadap $\mathrm{Y}$, dan variabel $\mathrm{X}_{2}$ terhadap $\mathrm{Y}$.

Uji normalitas menggunakan One-Sample Kolmogorov-Smirnov Test dengan melihat nilai $\mathrm{Z}$ dan nilai sig. Berdasarkan hasil pengujian diperoleh $\mathrm{Z}=1,062$ dan Sig. $=0,210>0,05$. Hal ini berarti asumsi atau persyaratan analisis regresi terpenuhi. 
Uji multikolininearitas dilakukan dengan melihat nilai Tolerance 0,542>0,1 atau Varian Inflation Factor (VIF) $1,844<10$. Sehingga dapat dinyatakan bahwa tidak ada multikolinearitas antara variabel $\mathrm{X}_{1}$ dan $\mathrm{X}_{2}$ pada analisis regresi ganda ini

Untuk mendeteksi adanya heteroskedastisitas adalah dengan membuat scatterplot antara standardized Residual (ZRESID) dan Standardized Predicted Value (Y topi).

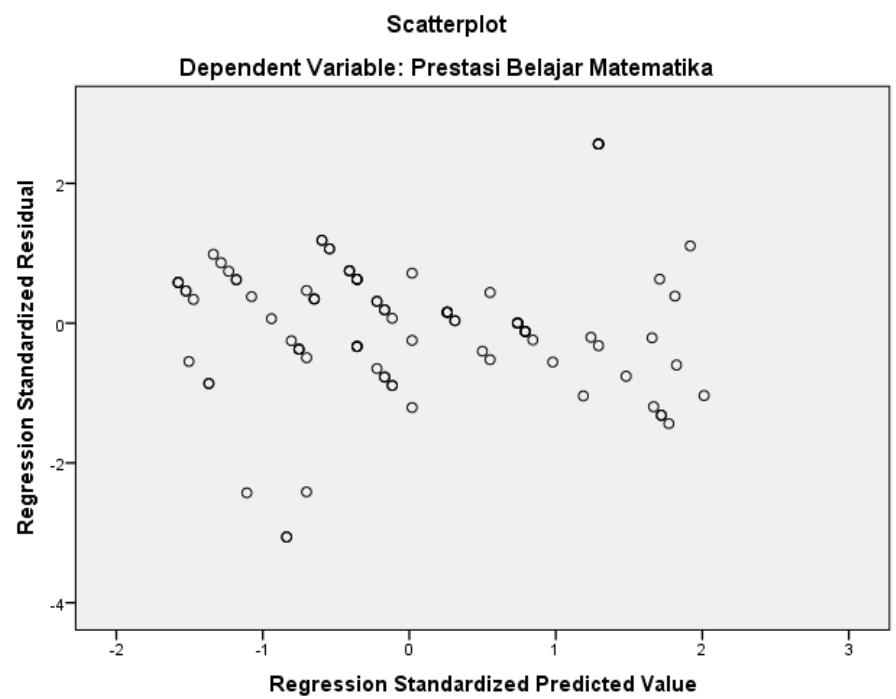

Gambar 2 Scatterplot Uji Heteroskedastisitas

Berdasarkan Gambar 1 dapat kita simpulkan bahwa tidak terjadi masalah heteroskedastisitas, sehingga dapat dipakai untuk memprediksi variabel prestasi belajar matematika $(\mathrm{Y})$ berdasarkan partisipasi siswa dalam organisasi kesiswaan $\left(\mathrm{X}_{1}\right)$ dan perilaku belajar $\left(\mathrm{X}_{2}\right)$

Persamaan regresi ganda yang diperoleh dinyatakan dengan $\hat{Y}=53,316+0,126 \mathrm{X}_{1}+$ $0,328 \mathrm{X}_{2}$. Hal ini memiliki pengertian sebagai berikut :

a) Apabila variabel lain bernilai konstan, maka nilai $\mathrm{Y}$ akan berubah dengan sendirinya sebesar nilai konstanta, yaitu 53,316

b) Apabila variabel lain bernilai konstan maka nilai $Y$ akan berubah sebesar 0,126 setiap satu satuan $\mathrm{X}_{1}$

c) Apabila variabel lain bernilai konstan maka nilai $\mathrm{Y}$ akan berubah sebesar 0,328 setiap satu satuan $\mathrm{X}_{2}$

Hasil Pengujian Signifikansi Koefisien Regresi Variabel $X_{1}$ dan $X_{2}$ terhadap Y dengan Anova menghasilkan nilai $F_{\text {hitung }}=253,957$ dan Sig. 0,000 < 0,05. Ini berarti terdapat pengaruh yang signifikan partisipasi siswa $\left(\mathrm{X}_{1}\right)$ dalam organisasi kesiswaan $\left(\mathrm{X}_{2}\right)$ dan perilaku belajar secara bersama-sama terhadap prestasi belajar matematika (Y). Pengaruh $\mathrm{X}_{1}$ dan $\mathrm{X}_{2}$ terhadap Y memberikan kostribusi sebesar 84,7\% (R square).

Selanjutnya uji parsial variabel $X_{1}$ terhadap $Y$ diperoleh $t_{\text {hitung }}=9,348$ dan Sig. $0,000<$ 0,05 , hal ini berarti terdapat pengaruh yang signifikan partisipasi siswa $\left(\mathrm{X}_{1}\right)$ dalam organisasi kesiswaan terhadap prestasi belajar matematika (Y), dan hasil uji parsial variabel $\mathrm{X}_{2}$ terhadap $Y$ diperoleh $t_{\text {hitung }}=8,779$ dan Sig. $0,000<0,05$ yang berarti terdapat pengaruh yang signifikan perilaku belajar $\left(\mathrm{X}_{2}\right)$ terhadap prestasi belajar matematika $(\mathrm{Y})$. Dengan melihat Koefisien Determinasi, maka diperoleh kontribusi variabel $\mathrm{X}_{1}$ terhadap y sebesar $43,87 \%$, dan pengaruh variabel $\mathrm{X}_{2}$ terhadap Y sebesar 40,76\%.

\section{Pembahasan}

Berdasarkan hasil penelitian di atas menyimpulkan bahwa partisipasi siswa dalam organisasi kesiswaan dan perilaku belajar secara bersama-sama telah memberikan pengaruh positif terhadap peningkatan prestasi belajar matematika siswa SMK Negeri di Kabupaten Bogor. Hal ini mengandung arti bahwa semakin tinggi tingkat partisipasi siswa dalam 


\section{SCIENCE : Jurnal Inovasi Pendidikan Matematika dan IPA Vol. 1 No. 3 November 2021 e-ISSN : 2797-1031 | p-ISSN : 2797-0744}

organisasi kesiswaan dan perilaku belajar maka akan memberikan peningkatan terhadap prestasi belajar matematika. Begitu pula sebaliknya semakin rendah tingkat partisipasi siswa dalam organisasi kesiswaan dan perilaku belajar maka akan memberikan penurunan terhadap prestasi belajar matematika. Besarnya pengaruh partisipasi siswa dalam organisasi kesiswaan dan perilaku belajar secara bersama-sama adalah $84,7 \%$ terhadap variabel prestasi belajar matematika, sisanya 15,3\% dipengaruhi variabel lain di luar model regresi ini.

Hal ini diperkuat oleh hasil penelitian Ningsih, Bardi, Harun (2017) yang menyatakan bahwa terdapat hubungan yang positif dan signifikan antara keaktifan siswa dalam kegiatan ekstrakurikuler dan perilaku belajar dengan hasil belajar. Artinya semakin baik keaktifan siswa dalam kegiatan ekstrakurikuler dan perilaku belajar maka semakin baik pula hasil belajar siswa.

Menurut Ahmadi dan Supriyono (2004), prestasi belajar yang dicapai seseorang merupakan hasil interaksi berbagai faktor yang mempengaruhinya baik dalam diri (faktor internal) dan dari luar (faktor eksternal). Salah satu faktor internal yang dimaksud adalah kebiasaan. Kebiasaan yang dimaksud dalam hal ini adalah kebiasaan belajar, yang mana bisa ditafsirkan sebagai perilaku belajar, hal ini sesuai dengan apa yang diungkapkan oleh Syah (2010), bahwa salah satu perwujudan perilaku belajar biasanya tampak dalam perubahanperubahan kebiasaaan.

Sementara dari faktor eksternal adalah lingkungan sekolah. Lingkungan sekolah yang dimaksud di sini adalah bagaimana siswa bergaul dengan siswa lain dalam sebuah lembaga/organisasi kesiswaan yang ada di sekolah, yang dalam hal ini dinaungi oleh Organisasi Siswa Intra Sekolah (OSIS), yang di dalamnya juga mengatur beberapa sub organisasi kecil pembantu dalam bentuk kegiatan-kegiatan ekstrakurikuler. Hal ini sesuai dengan apa yang diamanatkan dalam Peraturan Menteri Pendidikan Nasional Republik Indonesia Nomor 39 Tahun 2008 tentang Pembinaan Kesiswaan, yang menyebutkan bahwa "pembinaan kesiswaan dilaksanakan melalui kegiatan ekstrakurikuler dan kokurikuler. Salah satu lembaga yang menaungi bentuk kegiatan tersebut di sekolah adalah Organisasi Siswa Intra Sekolah (OSIS)”.

Maka berdasarkan hasil penelitian terdahulu serta teori mengenai prestasi belajar dapat kita simpulkan bahwa partisipasi siswa dalam organisasi kesiswaan dan perilaku belajar berpengaruh terhadap prestasi belajar.

Partisipasi siswa dalam organisasi kesiswaan merupakan keikutsertaan dari para siswa dalam rangka proses belajar untuk meningkatkan kemampuan diri, baik dari segi fisik maupun pemikiran, mengembangkan pengetahuan dan keterampilan siswa sehingga dapat memberikan pengalaman belajar untuk menunjang kegiatan di sekolah, khususnya kegiatan akademik.

Hal tersebut dapat memberikan manfaat untuk mengembangkan minat baru, menanamkan rasa tanggung jawab sebagai warga negara melalui pengalaman-pengalaman pada berbagai aspek kegiatan, kerjasama, kegiatan mandiri, melatih kemampuan berbicara, menambah pengetahuan umum dan aktual, memahami arti penting kepemimpinan, dapat memecahkan masalah secara rasional, dan sebagai wadah berkarya meningkatkan kemampuan inovatif dan kreativitas.

Rutinitas yang dilakukan dalam setiap kegiatan di organisasi akan menjadi sebuah kebiasaan positif yang akan menghasilkan siswa dengan pribadi yang mampu untuk bekerjasama, mandiri, berbicara secara lugas (komunikatif), calon pemimpin, problem solver dalam lingkungannya, serta siswa yang penuh dengan ide-ide yang mampu dituangkan secara nyata dalam keseharian (inovatif dan kreatif).

Lama kelamaan rutinitas tersebut tidak hanya menjadi hal yang dilakukan di dalam organisasinya, tapi juga dilakukan pada setiap aktivitas di mana pun dia berada, termasuk salah satunya adalah ketika siswa tersebut belajar. Nilai-nilai rutinitas organisasi kini menjadi nilainilai rutinitas dalam kegiatan belajar (perilaku belajar). Sehingga terjadi perubahan perilaku belajar siswa ke arah yang lebih baik, sehingga membawa dampak pada proses belajar yang lebih baik dan tentunya diiringi juga dengan hasil belajar (prestasi belajar) yang baik juga. 


\section{KESIMPULAN}

Berdasarkan pembahasan hasil penelitian, maka penelitian ini telah berhasil menjawab hipotesis yang diajukan. Dengan demikian kesimpulan dari hasil penelitian ini adalah: (1) Peningkatan partisipasi siswa dalam organisasi kesiswaan dan perilaku belajar secara bersamasama berpengaruh pada peningkatan prestasi belajar matematika, besarnya pengaruh partisipasi siswa dalam organisasi kesiswaan dan perilaku belajar terhadap prestasi belajar matematika adalah $84,7 \%$ dan sisanya $15,3 \%$ dipengaruhi variabel lain di luar model regresi ini. (2) Peningkatan partisipasi siswa dalam organisasi kesiswaan berpengaruh pada peningkatan prestasi belajar matematika, besarnya pengaruh partisipasi siswa dalam organisasi kesiswaan terhadap prestasi belajar matematika adalah 43,87\%. (3) Peningkatan perilaku belajar berpengaruh pada peningkatan prestasi belajar matematika, besarnya pengaruh perilaku belajar terhadap prestasi belajar matematika adalah $40,76 \%$.

\section{DAFTAR PUSTAKA}

Ahmadi, A., \& Supriyono, W. (2004). Psikologi Belajar. Jakarta: Rineka Cipta.

Departemen Pendidikan Nasional. (2007). Model-model Pembelajaran Matematika dan Ilmu Pengetahuan Alam. Jakarta: Direktorat PSLB

Kemendikbud. (2018). Hasil PISA Indonesia 2018: Akses Makin Meluas, Saatnya Tingkatkan Kualitas. Diakses pada 10 Desember 2018 dari https://www. Kemdikbud.go.id/main/blog/2019/12/hasil-pisa-indonesia-2018-akses-makin-meluassaatnya-ting-katkan-kualitas

Kemendikbud. (2018). Laporan Hasil Ujian Nasional. Diakses pada 20 Desember 2018 dari https://hasilun.puspendik.kemdikbud.go.id/\#2017!smk!capaian!99\&99\&999!T\&T\& T\&T\&1\&unbk!1!\&

Masykur Ag, M., \& Fathani, A.H. (2007). Mathematical Intelligence. Yogyakarta: Ar-ruzz Media.

Peraturan Menteri Pendidikan Nasional 2008 No. 39, Pembinaan Kesiswaan

Syah, M. (2010). Psikologi Pendidikan dengan Pendekatan Baru. Bandung: Remaja Rosdakarya.

Sugiyono. (2013). Metode Penelitian Kuantitatif, Kualitatif, dan R\&D. Bandung: Alfabeta

Veradillah Yuliya Ningsih, V.Y., Bardi, S., \& Harun, M.Y. (2017). Hubungan Keaktifan Siswa dalam Kegiatan Ekstrakurikuler dan Perilaku Belajar dengan Hasil Belajar Geografi Kelas XI IS SMA Negeri 5 Banda Aceh. Skripsi. Pendidikan Geografi FKIP Unsyiah. Banda Aceh. 